\title{
A rare cause of malnutrition: Intestinal tuberculosis
}

\author{
Malnütrisyonun nadir bir nedeni: İntestinal tüberküloz \\ Ömer Yılmaz*, Sare Şipal, Hilmi Ataseven, Ömer Topdă̆ı
}

Department of Gastroenterology (Assoc. Prof. Ö. Yılmaz, MD.), Department of Pathology (Assist. Prof. S. Şipal, MD.), Department of Internal Medicine (Ö. Topdağı, MD.), Atatürk University School of Medicine, TR-25050 Erzurum, Department of Gastroenterology (Assoc. Prof. H. Ataseven), Cumhuriyet University School of Medicine, TR-58140 Sivas

\begin{abstract}
Extrapulmonary manifestations of tuberculosis are an uncommon. Intestinal tuberculosis (ITB) is rare, but it remains a life-threatening disease unless diagnosed. Due to the lack of specific signs and symptoms, diagnosis of ITB can be difficult. A 27-year-old Turkish woman was admitted to our clinic with a 6-month history of abdominal pain, fever and weight loss. Colonoscopy was performed. At colonoscopy, there was detected in the mucosal lesions in the terminal ileum and caecum. On colonoscopy, deformed ileocaecal valve, strictures in caecum and terminal ileum, mucosal nodules were detected. Multiple biopsy specimens were taken from the active lesion. The diagnosis was made by demonstration of acid-fast bacilli and epithelioid cell granulomas in the colonoscopic biopsy specimens. The lesion was diagnosed as ITB. Quadruple therapy with antiTBC drugs for 1 year was ordered. The patient was discharged from hospital two months without any other complications. Intestinal TB is a treatable and curable illness.
\end{abstract}

Keywords: İntestinal tuberculosis, malnutrition, diagnosis

Özet

Tüberkülozun ekstrapulmoner manifestasyonları nadirdir. İntestinal tüberküloz (İTB) nadir olmasına rağmen tanı konmadığı zaman hayatı tehdit edebilir. Spesifik bulgu ve semptomlarının olmamasından dolayı İTB' nin tanısı zor olabilmektedir. Yirmi yedi yaşında kadın hasta 6 aydır süren karın ağrısı, ateş ve kilo kaybı şikayetleriyle kliniğimize kabul edildi. Kolonoskopi yapıldı. Kolonoskopide terminal ileum ve çekumda mokuzal lezyonlar tespit edildi. Kolonoskopide deforme ileoçekal valv, striktürler, mukozal nodüller tespit edildi. Aktif lezyonlardan çok sayıda biyopsiler alındı. Biyopside aside dirençli basil ve epiteloid granumlar görüldü. Hastaya İTB tanısı konuldu. Bir yıl sürmesi planlanan dörtlü anti-TBC ilaç tedavisi başlandı. Hasta her hangi bir komplikasyon olmadan iki ay sonra taburcu edildi. İTB tamamen tedavi edilebilir bir hastalıktır.

Anahtar sözcükler: İntestinal tüberküloz, malnütrisyon, tanı

Geliş tarihi/Received: January 29, 2013; Kabul tarihi/Accepted: March 04, 2013

*Corresponding author:

Dr. Ömer Yılmaz, Gastroenteroloji Bilim Dalı, Atatürk Üniversitesi Tıp Fakültesi, TR-25050 Erzurum. E-mail: yilmazomer27@ hotmail.com

\section{Introduction}

Tuberculosis (TB) can cause lesion any part of the gastrointestinal tract, from mouth to anus [1]. By the mid-20th century, all forms of TB had declined considerably in developed countries, due to various causes such as increased standards of living, control of bovine TB throughout slaughter of infected cattle herds, pasteurization of milk products, and the discover of antituberculous drugs [2]. In recent years, in developing countries, increasing incidence of tuberculosis is associated with poverty, scarcity, excess population, illiteracy, and limited access to fitness care facilities. On the other hand, the incidence of TB has been increasing in the developed country, owing to the AIDS epidemic, transglobal migration, IV drug abuse, an aging population, and an increase in the amount of immunsupressed patients [3]. The frequency of ITB has increased again 
together with an overall resurgence of TB [4]. ITB is a complex infection and have different symptoms that are non-specific $[5,6]$. A lack of experience in a region with a low commonness of TB might have contributed to the delay in making the accurate diagnosis and treatment [7]. We report a case of a 27-year-old female patient with a 6mounth history of $15 \mathrm{~kg}$ weight loss, abdominal pain and diarrhea due to intestinal tuberculosis.

\section{Case report}

A 27-year-old Turkish woman presented with a 6-month history of fever, anorexia, loss of weight, abdominal pain. The patient had a history of recurrent episodes of watery stools (6-8 watery stools per day for) at the start for 6 months. Physical examination detected a subfebrile $\left(37^{\circ} \mathrm{C}\right)$, pale, cachectic-looking, lower abdominal tenderness and body mass index was low (weight, $44 \mathrm{~kg}$; height, $1.65 \mathrm{~m}$ ). The liver, spleen and lymph nodes were not enlarged. In history was present consumption of unpasteurised milk. Laboratory tests showed hypochromic anemia (hemoglobin $10.3 \mathrm{~g} / \mathrm{dL}$ ), normal white blood cells $\left(8,000 / \mathrm{mm}^{3}\right)$, low serum albumin $(2.01 \mathrm{~g} / \mathrm{dL})$, low serum calcium $(7.1$ $\mathrm{mg} / \mathrm{dL})$, high erythrocyte sedimentation rate $(110 \mathrm{~mm} / \mathrm{h})$, and high CRP rate $(10.9 \mathrm{mg} / \mathrm{dL}$, upper limit $0.5 \mathrm{mg} / \mathrm{dL}$ ). Other biochemical parameters were normal. In searching for the source of the fever, blood, sputum, urine cultures were taken and direct microscopies of urine, stool, and sputum were also examined. Direct microscopy of stool was seen acidfast bacillus, but others were negative. Test for HIV antibodies was performed, and was negative. Chest x-ray showed no abnormalities, but CT scan of the abdomen showed irregular thickening of the caecum in the abdomen. Gastrointestinal tract was examined from rectum to terminal ileum, with colonoscopy. There was gross nodularity with hyperemia, deformed ileocaecal valve and stricture in caecum and terminal ileum (Figure 1). Multiple forceps biopsy specimens were taken from the base and margin of lesions. The biopsy specimens were prepared for both standard histopathologic evaluation (H\&E staining) and bacteriologic study (smear for Ziehl-Neelsen stain). Acid-fast bacillus was detected in the formalin fixed sections stained with the

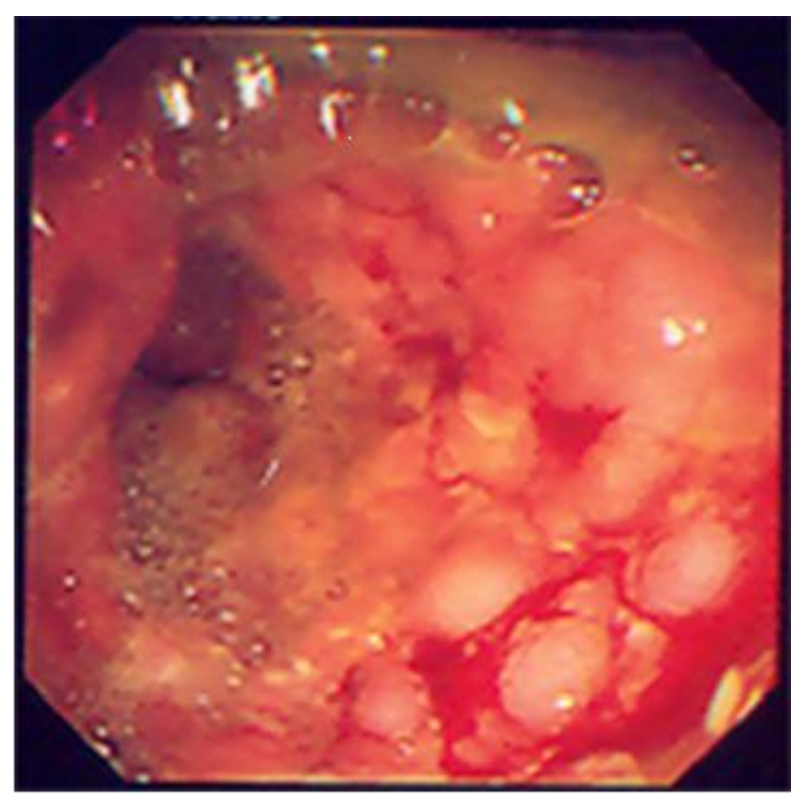

Figure 1. Colonoscopy showing multiple nodular lesions and a stricture in the terminal ileum.

Ziehl-Neelsen stain (Figure 2). In the sections stained with H\&E, well-formed, epithelioid-cell granulomas were present in the specimens (Figure 3). Pulmonary TB was not diagnosed on the basis of bacteriological (sputum smear and culture for 
mycobacteria) and radiological investigations. The patient was accepted as tuberculosis of the intestine which was supported by clinical and radiological features. Antituberculous treatment was ordered. The treatment consisted of four drugs (isoniaside $300 \mathrm{mg}$ orally daily, pyrasinamide $2000 \mathrm{mg}$ orally daily, ethambutol $1500 \mathrm{mg}$ orally daily, rifampicin $600 \mathrm{mg}$ orally daily) for a two-month period and two drugs (isoniaside, rifampicin) for the rest of the therapy period (10 months). The patient began to gain weight and showed improvement in her general well being, she was hospitalized for a period of 2 months and received antituberculous therapy under direct observation. The patient responded rapidly to antituberculosis chemotherapy. Diarrhea and weight loss improved after one month. The parameters evaluated for response during follow-up visits were body weight and hemoglobin. On discharge she had gained $6 \mathrm{~kg}$ in weight $(50 \mathrm{~kg})$ and her haemoglobin was $11.9 \mathrm{~g} / \mathrm{dL}$. When she was seen 3 months later, she was in good health, had gained a further $2 \mathrm{~kg}(52 \mathrm{~kg})$, with normal hematological and biochemical parameters. The patient underwent colonoscopy after 3 months of treatment. Mucosal lesions had lost in the caecum and terminal ileum.

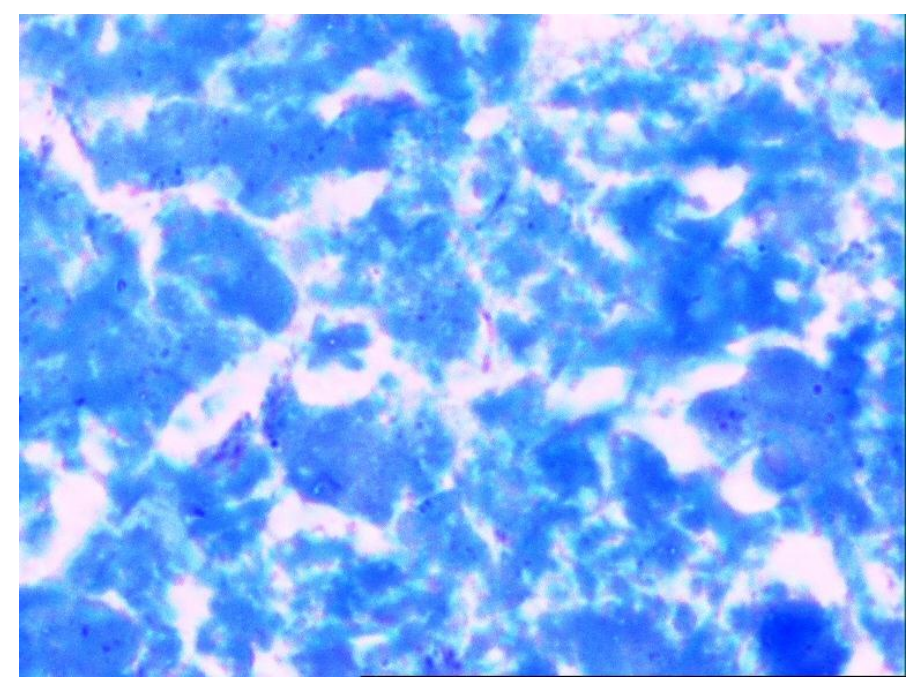

Figure 2. Scattered epithelioid cells on a necrotic background. Note the acid-fast bacilli (Ziehl-Neelsen, original magnificationX400).

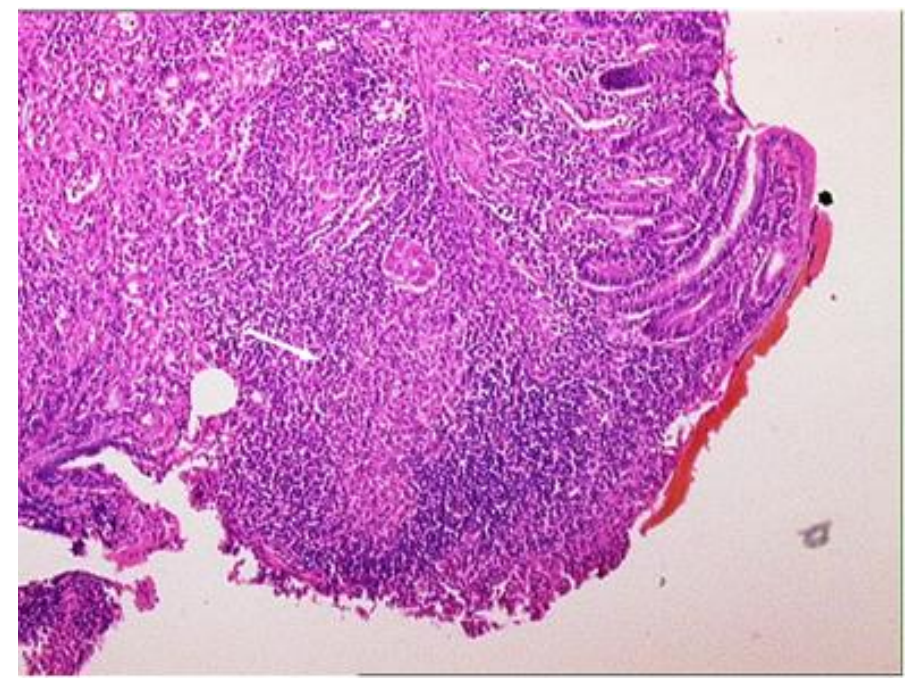

Figure 3. A colonic biopsy with dense inflammation and a collection of epithelioid histiocytes forming an ill-formed granuloma (arrow) (hematoxylin-eosin, original magnification X100). 


\section{Discussion}

In recent years, in world-wide the incidence of ITB has been increasing along with the overall resurgence of TB [8]. The pathophysiology of ITB can be attributed to hematogenous spread from active pulmonary or miliary TB, contiguous spread from neighbor organs, swallowing of infected sputum in active pulmonary TB, or intake of contaminated milk products $[4,6,9]$. Neither past history of treatment for tuberculosis nor a family history of tuberculosis was present in our patient. Mycobacterium bovis can be transmitted to humans during consumption of unpasteurised milk products from infected cows [10]. Mycobacterium bovis infection was suspected in our patient because of consumed unpasteurised milk before the onset of abdominal symptoms.

The symptoms of intestinal TB are non-specific; a high index of doubt is so important to ensure an appropriate diagnosis; missed or delayed identification can result in preventable morbidity and mortality $[11,12]$. The most frequent symptoms of ITB are diarrhea, weight loss, anorexia, fever, anemia, and lower gastrointestinal hemorrhage. Lower abdominal pain and distension and/or palpable abdominal mass are also relatively common physical examination findings [13, 14]. Khan et al. [6] reported that study which 209 patients with intestinal TB enrolled was detected abdominal pain in 93\%, weight loss in $47 \%$ of patients. Leung et al. [4] reported that the presenting symptoms of 22 with intestinal TB patients are the most frequent being abdominal pain $82 \%$, diarrhea $55 \%$, weight loss 55\%. Alvares et al. [9] were evaluated in 43 patients with colonic tuberculosis, reported abdominal pain $72 \%$, weight loss 56\%. Many of these signs and symptoms were present in our patient. In the patient was present later 6-month history of $15 \mathrm{~kg}$ weight loss and diarrhea.

Most commonly affected areas of gastrointestinal tract are the jejunoileum and ileocecum, which consist of $>75 \%$ of gastrointestinal TB sites [2]. Because of comparatively frequent involvement of terminal ileum in intestinal TB is to either physiological stasis, large surface area of this part of the intestine, entire digestion of food and abundant lymph nodes in the area $[4,6,15]$. In consequence of the increased use of colonoscopy may have facilitated early diagnosis of intestinal TB [5]. In patients with intestinal TB on colonoscopy may be detected various appearance such as, ulcers, strictures, nodules, pseudo polyps, fibrous bands, fistulas, and deformed ileocaecal valve [16]. In our patient, on colonoscopy were detected deformed ileocaecal valve, stricture and nodules. The most diagnostic histological lesions of intestinal TB are caseating granulomas, however their existence in colonoscopic biopsy specimens is highly variable (0-44\%) [17] Histological features of the granulomas associated with TB are frequently large and numerous, tend to coalesce, and include AFB [2, 18]. In our patient, the diagnosis of confirmed ITB was based on affected tissues of the following [1] histological evidence of granulomas, [2] demonstration of acid-fast bacilli (AFB) by Ziehl-Neelsen (ZN) stain. Culture of biopsies was not carried out.

The Mantoux test is positive in $70 \pm 86 \%$ of patients with TB, but has limited helpfulness in immuncompromised patients [2]. In our patient, this skin test was evaluated negative. PCR, extremely specific is not markedly sensitive (26.5 $\pm 75.0 \%)$ [7]. In this case was not carried out PCR because acid-fast bacilli were seen in histopathology examination.

Intestinal TB is completely treatable, provided that the diagnosis is made early enough and suitable treatment is ordered [6]. Antitubercular therapy with rifampicin $(10 \mathrm{mg} / \mathrm{kg})$ p. o., isoniazid (5 mg/kg) p. o., pyrazinamide $(30 \mathrm{mg} / \mathrm{kg})$ p. o., and ethambutol $(15 \mathrm{mg} / \mathrm{kg})$ p. o. or streptomycin $(0.75 \pm 1.0 \mathrm{~g})$ i.m. was given for 2 months, followed by rifampicin (10 $\mathrm{mg} / \mathrm{kg}) \mathrm{p}$. o. and isoniazid $(5 \mathrm{mg} / \mathrm{kg})$ p. o. for an additional 8 months $[4,6,9,15]$. We ordered same as 4 anti-TB drugs and symptoms began improved after one month of treatment.

Intestinal TB is uncommon and curable disease. It should be kept in mind treatment resistant diarrhea of differential diagnosis, especially consumption of unpasteurised milk products in areas. 


\section{References}

1. Sharma MP, Bhatia V. Abdominal tuberculosis. Indian J Med Res 2004; 120: 305-15.

2. Horvath KD, Whelan RL. Intestinal tuberculosis: Return of an old disease. Am J Gastroenterol 1998; 93: 692-6.

3. Ara C, Söğütlü G, Yildiz R, Kocak O, Işık B, Yılmaz S, Kırımlığlu V. Spontaneous small bowel perforations due to intestinal tuberculosis should not be repaired by simple closure. J Gastrointest Surg 2005; 9: 514-7.

4. Leung VK, Law ST, Lam CW, Luk IS, Chau TN, Loke TK, Chan WH, Lam SH. Intestinal tuberculosis in a regional hospital in Hong Kong: A 10-year experience. Hong Kong Med J 2006; 12: 264-71.

5. Sato S, Yao K, Yao T, Schlemper RJ, Matsui T, Sakurai T, Iwashita A. Colonoscopy in the diagnosis of intestinal tuberculosis in asymptomatic patients. Gastrointest Endosc 2004; 59: 362-8.

6. Khan R, Abid S, Jafri W, Abbas Z, Hameed K, Ahmad Z. Diagnostic dilemma of abdominal tuberculosis in non-HIV patients: an ongoing challenge for physicians. World J Gastroenterol 2006; 12: 6371-5.

7. Gan HT, Chen YQ, Ouyang Q, Bu H, Yang XY. Differentiation between intestinal tuberculosis and Crohn's disease in endoscopic biopsy specimens by polymerase chain reaction. Am J Gastroenterol 2002; 97: 1446-51.

8. Marshall JB. Tuberculosis of the gastrointestinal tract and peritoneum. Am J Gastroenterol 1993; 88: 989-99.

9. Alvares JF, Devarbhavi H, Makhija P, Rao S, Kottoor R. Clinical, colonoscopic, and histological profile of colonic tuberculosis in a tertiary hospital. Endoscopy 2005; 37: 351-6.

10. Horsburgh CR, Nelson AM, Blaser MJ, Smith PD, Ravdin JI, Greenberg HB, Guerrant RL. Mycobacterial disease of the gastrointestinal tract, editors. Infections of the gastrointestinal tract. 2nd ed. Philadelphia: Lippincott Williams \& Wilkins 2002; 831-45.

11. Eisenach KD, Sifford MD, Cave MD, Bates JH, Crawford JT. Detection of mycobacterium tuberculosis in sputum samples using a polymerase chain reaction. Am Rev Respir Dis 1991; 144: 1160-3.

12. Peneau A, Moinard D, Berard I, Pascal O, Moisan JP. Detection of mycobacteria using the polymerase chain reaction. Eur J Clin Microbiol Infect Dis 1992; 11: 270-1.

13. Brandt MM, Bogner PN, Franklin GA. Intestinal tuberculosis presenting as a bowel obstruction. Am J Surg 2002; 183: 290-1.

14. Kim MP, Janz BA, Kasparian AS. Tuberculosis enteritis presenting as a small bowel obstruction. J Am Coll Surg 2005; 201: 478-9.

15. Polat KY, Aydınlı B, Yılmaz Ö, Aslan S, Gursan N, Öztürk G, Onbas O. Intestinal tuberculosis and secondary liver abscess. Mt Sinai J Med 2006; 73 : $887-90$.

16. Bhargava DK, Kushwaha AK, Dasarathy S, Shriniwas, Chopra P. Endoscopic diagnosis of segmental colonic tuberculosis. Gastrointest Endosc 1992; 38: 571-4.

17. Bhargava DK, Tandon HD, Chawla TC, Shriniwas, Tandon BN, Kapur BM. Diagnosis of ileocecal and colonic tuberculosis by colonoscopy. Gastrointest Endosc 1985; 31: 68-70.

18. Pulimood AB, Ramakrishna BS, Kurian G, Peter S, Patra S, Mathan VI, Mathan MM. Endoscopic mucosal biopsies are useful in distinguishing granulomatous colitis due to Crohn's disease from tuberculosis. Gut 1999; 45: 537-41. 